\title{
The Principles and Methods of English Neologism Translation
}

\author{
Xinfa Sun \\ College of Liberal Arts, Xi'an International University, Xi'an Shaanxi 710077, China
}

Keywords: English Neologism, Principle, Method.

\begin{abstract}
With the continuous development of the times, English as a global human communication is constantly enriched in the use of the progress. In order to adapt to the changes of the times and improve itself, a lot of new words and phrases come into being. Due to differences between neologisms' own characteristics and differences of the English and Chinese two languages, there is a big problem in the translation .By analyzing the connotation and the definition of English Neologisms, the paper probes into the principles and methods of its translation from the perspective of English Neologism classification, with the hope to promote the development of English translation and improve the English Chinese communication mode.
\end{abstract}

\section{Introduction}

The current age is an information age with explosive growth, English as a global language around the world. it is developing and complementary all the time. With the development of English, there is a distinctive feature is that the new vocabulary. New words have injected new vitality into English. Meanwhile, they have satisfied the needs of the human communication. Chinese as an ideographic language, is essentially different from English .How to translate the new words and phrases accurately and vividly, is the focus of current study for the academics in field of translation.

\section{The connotation and definition of English neologism}

With the rapid process of globalization, science and technology are changing and upgrading extremely fast, all walks of life are carrying out technological innovations, thought reform. With the new understanding and new innovation of the world, new words arise, that belong to new words and new phrases in the appropriate historical period, such as a word avian influenza (bird-flu). As time went by, new words and phrases have been kept in the dictionary. It usually uses the "neologism" to mean "new words and phrases" in English. According to the authoritative English Dictionary, Webster's New World Dictionary, new words and phrases include two connotations: one is the neologisms which arise with the progress of human beings, other is that the old words derive new meanings and methods by communicating with humans.

There are three defined ways to judge that whether a vocabulary is a neologism or not. Firstly, the word for a new period, generally speaking, the time range is in the last 15 years. Secondly, the word should be included in the authoritative dictionaries. Thirdly, as for the old word, old words derive new meaning and new methods should be widely accepted and used in people's daily life.

\section{The classification of English neologism}

On the basis of vocabulary itself, neologisms can be divided into the derived terms, foreign words, abbreviations and so on, but according to the neologisms with the change of all walks of life, the author thinks that the classification of new words based on the difference of various industry sectors is more appropriate. On the basis of a large amount of literature, the author makes a summary: the English neologism pays more attention to military, political, economic, technological and social fields.

Political activities are uncanny, although peace and development are the themes of the current 
times. Some areas are still very volatile. Frequent political movement spread through the news media, it produced a large number of new words and phrases on military, politics. For example, the last century, in the Middle East, terrorist activities have occurred frequently, the United Nations dispatched a number of troops to peacekeeping operations, and that promoted the United Nations peacekeeping force (the implementation force) and new words.

With the accelerated process of globalization, global economic connection and communication are further strengthened, that result in making a number of words in order to adjust to the economic forms of all kinds of industries, so that the new word cyber-commerce is arisen with the rapid development of the Internet.

The competition of the current era is the competition of science and technology. The fierce technological competition promoted the innovations of science and technology among the countries and enterprises. The great progress of science and technology created the conditions for the neologism, the neologisms are circulated and used in the correlative industry at first, and then gradually extended to all kinds of segments of society. For example, the advanced Internet produced new words and phrases such as E-mail, web-shopping and so on.

With improving the quality of life for human beings, it promoted the level of Medicare in a certain degree produced a series of new words and phrases on the medical field. Take test-tube baby for example, the new word is produced under the background of meet the needs of human reproduction.

All states and nations are in continuous development that produced a lot of neologisms on the field of social development. Such as the word white collar in the enterprises, is popular with esports gaming League of Legends (LOL) and so on.

\section{The principles of English neologism translation}

The English neologism translation generates a feature of updated time, there is a big problem in translation. Above mentioned that the new English words are produced by the development of human society, therefore, while translating the new words, it must be accurate, at the same time, making translations popularized, fitting with the people's daily habits, in order to use conveniently.

Whatever translation work is, the first should ensure the accuracy of translation. In the process of the English neologism translation, we should try to express the original meaning. For example, "smart on Crime (white-collar crime),"it doesn't be translated into "white collar crime" directly. "White collar" is commonly known as the modern corporate office personnel, this category of personnel accept high education. So when translating "white-collar crime", we can combine it with "white collar" this group, then it is translated into "smart on crime." The translation of "Smart on crime" faithfully expresses the western style under the background of English, while also considering the mode of Chinese thinking, that is accurate and prefect.

Language is a tool of communication, when translating the new words and phrases, translators should fully take into account the requirements of people, spare no effort to make the translation popularized. The result of translation should enable be understood and accepted by people. This is an inevitable demand that it is carried out by itself meaning. A translation result which is impossible to be understood is unable to assume the culture, economy, communication and other tasks. For example, the Modern English Neologism Dictionary has made a mistake in translation, the word "go llatline" was translated into "lost the wave mode of expressing the main function of body ", in fact ,the word is refers to death with the euphemism of EEG into a straight line.

Some translation principles of new words and phrases widely have accepted by people, at that time, there is no need to "kouziyan" and makes new translations for it. Using the reciprocal and conventional translations, that can let people quickly accept new concepts of words and phrases. For example, in Modern English Neologism Dictionary, that ever has made the "Anti-lock brake system" translate into "anti-skidding brake system stuck wheel", which is should not, firstly, it will cause make readers misunderstanding, increase the difficulty of understanding for readers , secondly, it is not beneficial for spreading the new words and phrases. The most appropriate method of translation should follow the related Chinese language that is the "anti-lock braking system". 
The principles of accuracy, popularization and convention are the three components of English new words and phrases, they should be interrelated, complemented and coordinated with each other. In the context of concrete translation of English neologisms, we should compare with these three principles and make integrated translation.

\section{The methods of English neologism translation}

Translation has two aspects of content, the first one is language activities, and the other one is the activities among different cultures. The current translation methods are literal translation, free translation, combination of literal translation and free translation, transliteration, partial translation, translations of a word and so on. In the translation of English new words and phrases, the professional translators mainly discuss about the literal translation, free translation. Faced with main areas of English new words and phrases, the author focuses on making an analysis on four methods which are literal translation, free translation, transliteration, combination of literal translation and free translation.

Literal translation is the simple method on the basis of the original meaning of text and culture, as well as on the condition of not causing the cultural misunderstanding. The author thinks with the similar expression situations between English and Chinese, we should take into consideration the method of literal translation. Such as the idiom "blood is thicker than water" and the English proverb "Blood is "blood is thicker than water" and the English saying "Blood is thicker than water", the two sentences express the meaning very similarly, so it fits the literal translation. The political word "Macro-control" and the "macro" is basically the same, it can adopt to the literal translation directly. The advantage of the literal translation is that we can keep with real English "origin". On the translation of the English neologisms, so far, literal translation is mainly used political, scientific, technological and other fields. For example, we can translate "Clinton-omics" directly into "policy Clinton economic policies" and so on.

There are aspects of content on translation. The significance of free translation is that solving the contradictions among different cultures, translating that vocabulary with strong ethnic characteristics by paying more attention to metaphor. Just like an English proverb, "Half the world knows not how the other half livers" can be translated as "the well-fed don't know how." If using literal translation, the results will be much complex, and against the principle of popularization. The free translation can ensure the translation based on the principle as well as the principle of popularization, and make the two languages and cultures interlink and connect. On the translation of English neologisms, transliteration is often used in these areas such as Internet-related industries, traditional English proverb and so on. For example, "back-to-back" is not "two round-trip air tickets for the price" in literal translation, but "double round trip ticket." by using free translation.

Due to the different idea of life between the West and China, some new English words and phrases cannot find corresponding harmonic words in Chinese. The function of transliteration is embodied in solving those conflicts. For example, "gene" is a word which is derived from "gene" abroad. While translating English neologisms by transliteration, it usually has advanced, fashion and other means. "Cool" is just for "cool" by transliteration.

English as the language which is used the most widely at present, with the advent of the information age, English has produced a large number of new words and phrases with a regional characteristic in the process of using. If these words use the literal translation, the result will be stiff, if using free translation, it will have great deviations from the original meaning. When the translators meet this awkward situation, it is a great solution to combine the literal translation with free translation.

\section{Conclusion}

Translation is not only a simple language translation, it draws more attention to "original" of cultural level translation. The task of translation is to provide the closest result of the original to readers. Translating the English new words and phrases is has some difficulties, in many cases ,it 
asks translators to know more about the English culture or have a deep understanding for the development of industry. Therefore, when translating new words and phrases, we should grasp the three principles of translation, maintain its own cultural characteristics on the basis of ensure not to make a great deviation by literal translation, free translation and other methods.

The translation of English new words and phrases needs to bear the everyday test, it can eventually be in the authoritative dictionary, and become the normal English words. The author extends the principles and methods of English neologism translation according to making a summary on the connotation and classification of English neologism translation, and hopes that devoting to providing some inspirations for the development of Chinese English neologism translation, making great progress on promoting our country English learners.

\section{Acknowledgement}

The reform and practice of College English Evaluation Mode based on the reform of curriculum system JK0327

Northwestern University graduate education teaching reform project YJG13003.

Northwestern University teaching quality engineering project: $03 Y 027$.

\section{References}

[1] Xiaoshu Liu, Lili Yang. Analysis on English Neologism Translation [J].Journal of Xianning University. 2010 (11)

[2] Fengying Liu. Study on Word Formation and Translation of English Neologisms [J].Journal of Jixi University. 2009 (05)

[3] Changhe Xu. Principles and methods of English Neologism Translation [J]. Journal of Zhejiang Ocean University (Humanities Science). 2009 (01)

[4] Junling Qu. Production and translation of English neologisms [J]. Journal of Shangluo Teachers College. 2002 (02)

[5] Mingdong Liu, Xuejun Jiang. English Neologism and its translation [J]. Journal of Xi'an Foreign Languages University. 2002 (01) 